(C) І.С. Пуляєва, 2020

УДК 616.133-007.271-052-089.163

\title{
Обстеження хворих зі стенозами сонних артерій перед хірургічним лікуванням
}

\author{
І.С. Пуляєва
}

Інститут загальної та невідкладної хірургії ім. В.Т. Зайцева Національної академії медичних наук Украӥни, Харків

\section{Реферат}

У роботі проаналізовано результати комплексного обстеження та хірургічного лікування 230 пацієнтів із атеросклеротичним ураженням сонних артерій. У дослідження включали пацієнтів із: симптоматичним стенозом внутрішньої сонної артерії (ВСА) більше 50\%; асимптоматичним стенозом ВСА більше 70\%; нестабільною бляшкою ВСА, порушенням зору. Ми використовували шкалу тяжкості інсульту NIHSS. Пацієнти із симптоматичним ураженням BCA $є$ найбільш ризиковою групою щодо розвитку повторного інсульту, вогнище ішемії, стан неврологічного дефіциту необхідні для прогнозування ефективності та успішності хірургічного лікування.

Ключові слова: стеноз сонних артерій, неврологічна шкала.

Вступ. В Україні сьогодні 3 млн. осіб хворіють на цереброваскулярні захворювання (ЦВ3) різного ступеня тяжкості, найтяжчою формою $є$ мозкові інсульти, яких в Україні реєструється близько 110-130 тис. випадків щорічно [1].

Серед всіх видів інсультів домінують ішемічні ураження мозку, які складають 70-85\%, крововиливи в мозок трапляються в 20-25\% випадків, а нетравматичні субарахноїдальні крововиливи складають 5\% [3].

Щорічно у світі на церебральний інсульт хворіють майже шість мільйонів осіб (за даними BOO3, у розвинутих країнах світу щорічно реєструють від 100 до 300 інсультів на кожні 100 тис. населення), а в Україні - більше 125 тис. [2].

Профілактика порушень мозкового кровообігу за ішемічним типом є найбільш актуальним завданням клінічної ангіоневрології [4]. Цереброваскулярна патологія знаходиться на першому місці серед причин стійкої втрати працездатності. Летальність впродовж першого року після інсульту складає 35-38\%, а в цілому порушення мозкового кровообігу $\epsilon$ причиною чверті усіх смертельних результатів [5,7]. Ураження церебральних артерій у хворих на ішемічну хворобу мозку після перенесеного гострого інсульту носить поширений характер [6].

Мета дослідження. Аналіз результатів комплексного обстеження та хірургічного лікування пацієнтів із атеросклеротичним ураженням сонних артерій.

Матеріали та методи. У роботі проаналізовано результати комплексного обстеження та хірургічного лікування 230 пацієнтів із атеросклеротичним ураженням сонних артерій, які знаходились на лікуванні у відділенні гострих захворювань судин ДУ «ІЗНХ ім. В.Т. Зайцева НАМН України» за період із 2013 по 2018 роки.

Віковий інтервал був від 48 до 83 років. Серед них чоловіки - 160 (69,5\%), жінки - 70 (30,5\%).
У дослідження включали пацієнтів із: симптоматичним стенозом ВСА більше 50\%; асимптоматичним стенозом ВСА більше 70\%; нестабільною бляшкою ВСА.

230 хворих розділили на 2 групи.

I група - 64 симптоматичні пацієнти. Це хворі зі стенозом ВСА після перенесеного гострого порушення мозкового кровообігу протягом шести місяців та хворі 3 ізольованим порушенням зору.

II група - 166 (72,2\%) асимптоматичних пацієнтів із верифікованим атеросклеротичним ураженням сонних артерій без проявів гострого ішемічного порушення мозкового кровообігу протягом останніх 6 місяців, які потребували хірургічного лікування другим етапом на серці, аорті й артеріях нижніх кінцівок, та інших органів і систем під загальним знеболенням та хворі 3 нестабільною бляшкою.

Стеноз сонних артерій був виявлений первинно при скринінгу за даними ультразвукового дослідження. Пацієнти, у яких виявлений гемодинамічно незначний стеноз сонної артерії до $50 \%$ із гладкостінною поверхнею при УЗД призначали консервативну терапію і контроль УЗД кожні 6 місяців. Пацієнти, у яких при УЗД визначався стеноз більше $50 \%$, було виконане додаткове дослідження спіральна комп'ютерна томографія 3 контрастуванням екстра- й інтракраніального відділу сонних і церебральних артерій. 3 них у 5 хворих діагностована нестабільна бляшка в гирлі внутрішньої сонної артерії (рис.1) і у 6 хворих стеноз більше $70 \%$. Перенесене раннє гостре порушення мозкового кровообігу за даними комп'ютерної томографії підтверджене у 2 хворих. У обох групах виконана еверсійна ендартеректомія в 165 випадках, у 55 випадках виконана каротидна ендартеректомія 3 вшиванням синтетичної латки, у зв'язку з необхідністю установки тимчасового шунта або протяжним стенозом. 


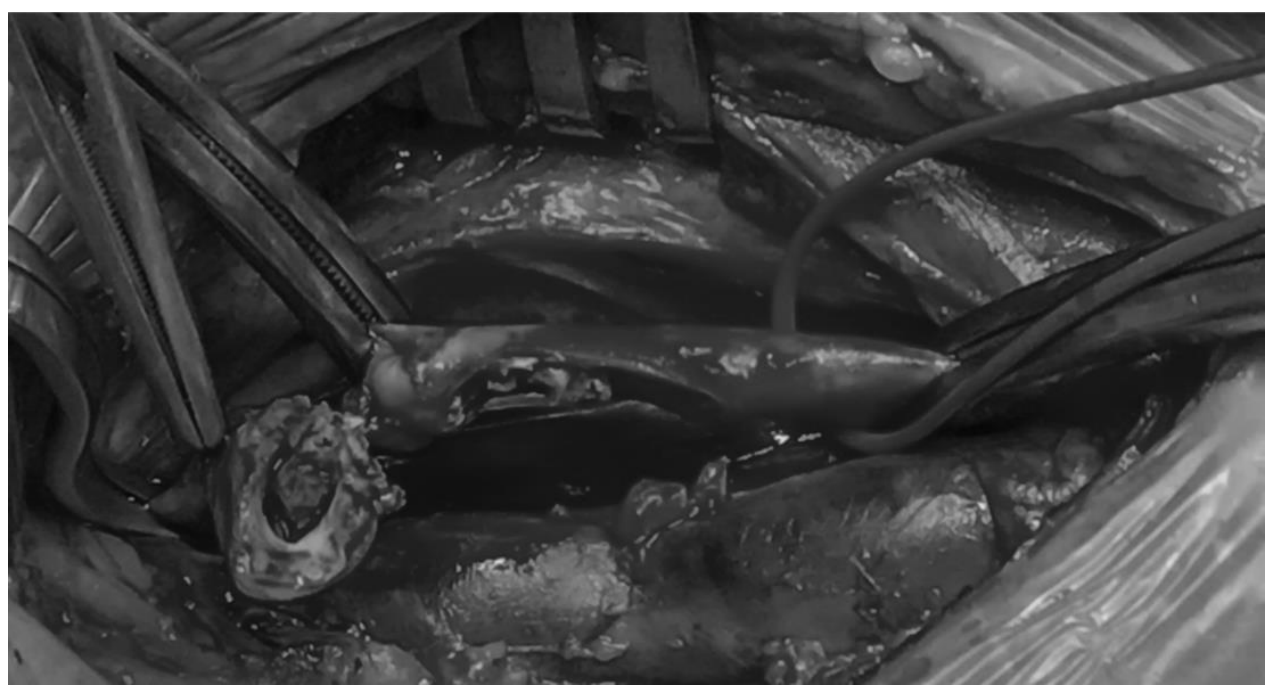

Рис. 1. Нестабільна бляшка ВСА у хворого з амаврозом.

Усім пацієнтам проводилися стандартні лабораторні й інструментальні методи обстеження. Усім пацієнтам виконувалося оперативне лікування під провідниковою анестезією, що дозволяла контролювати свідомість у період перетискання сонної артерії. За наявності неврологічного дефіциту виконували ендартеректомію 3 внутрішньої сонної артерії (ВСА) з використанням тимчасового шунта і вшиванням синтетичної латки. У післяопераційному періоді пацієнти отримували антибактеріальну терапію, дезагреганти та статини. У першу післяопераційну добу пацієнти знаходилися в ПІТ для моніторингу артеріального тиску. На третю добу пацієнти були виписані.

Особлива увага була прикута до питання про необхідність двомоментних втручань у пацієнтів, що мають клініку критичної ішемії нижніх кінцівок при асимптомному враженні сонних артерій. Існує точка зору, що при асимптомному каротидному стенозі операція КЕ не показана, оскільки не доведено зниження ризику розвитку інсульту. Проте відомо, що більш ніж у половині випадків пацієнти, що перенесли гостре порушення мозкового кровообігу, не мали в анамнезі TIA. Це положення підтверджують отримані нами результати. Оскільки у $80 \%$ хворих асимптомних неврологічно, при проведенні проби навантаження під час перетискання сонних артерій упродовж 7-40 хвилин не спостерігалося неврологічного дефіциту. I тільки у 20\% пацієнтів при проведенні проби навантаження 3 модельованою гіпоксією під час передавлення сонних артерій був виявлений низький резерв перфузії головного мозку. Каротидна ендартеректомія виконувалася першим етапом в 91,9\% випадків у хворих із критичною ішемією нижніх кінцівок при необхідності загальної анестезії. Другим етапом пацієнти були оперовані 3 приводу основного захворювання через 5-7 діб.

Пацієти 3 порушенням зору отримували консервативну терапію у офтальмолога та весь спектр діагностичних обстежень. При наявності атеросклерозу сонної артерії першим етапом виконува- ли хірургічне лікування, а другим - лікування патології зору, в 32\% випадків у хворих після каротидної ендартеректомії виявляли покращення зору. Перед хірургічним втручанням виконували комплексне обстеження хворих із залученням невролога, кардіолога та інших суміжних спеціалістів. Використовували класичні методики клінічного та лабораторного обстеження, проводили стандартну оцінку неврологічного статусу та виконували інструментальні методи обстеження (УЗДС, КТ, МРТ, ангіографія).

У передопераційному періоді проводили оцінку функціонального стану систем та органів хворого 3 метою виявлення та профілактики можливих інтраопераційних та післяопераційних ускладнень.

Враховуючи етіологію атеросклерозу, високу вірогідність ураження двох і більше артеріальних басейнів та локалізацію атеросклеротичних стенозів у сонних артеріях у передопераційному періоді, оцінювали соматичний та неврологічний статус пацієнта.

Враховуючи те, що показанням до КЕА є пацієнти як із симптоматичним, так і з асимптоматичним стенозом ВСА, оцінка неврологічного статусу $\epsilon$ надзвичайно важливою. Для оцінки вираженості неврологічного дефіциту, ступеня відновлення неврологічних функцій, проводили систему бальної оцінки різних клініко-неврологічних параметрів.

Ми використовували шкалу тяжкості інсульту національних інститутів здоров'я США (NIHSS) iз рекомендаціями оцінювання.

Визначення тяжкості інсульту за балами згідно 3 NIHSS:

$-\leq 5$ балів - легкий інсульт;

-6-13 балів - інсульт середньої тяжкості;

-14-20 балів - тяжкий інсульт;

->20 балів - дуже тяжкий інсульт.

Повторні оцінки неврологічного стану за допомогою Шкали тяжкості інсульту (NIHSS) проводять через 3 та 6 год. із моменту виявлення інсульту та в післяопераційному періоді. 
Хірургічне лікування виконували при легких інсультах та інсультах середньої тяжкості, при TIA, при порушенні зору.

На етапі діагностики виявлено різні типи порушень мозкового кровообігу: транзиторні ішемічні атаки ішемічний інсульт, стан після інсульту та повторний інсульт. Хворим виконували КТ або МРТ головного мозку. Наявність розміру ішемічного вогнища $є$ одним із ключових критеріїв вибору терміну КЕА. При наявності свіжого вогнища розміром до 2х3 см КЕА виконували протягом 2 місяців днів із моменту розвитку ГПМК. У випадку виявлення ішемічного вогнища більшого ніж $2 \times 3$ см, КЕА виконували через 5-6 тижнів від моменту розвитку ГІПМК. Хворим з тяжким соматичним станом виконували стентування.

Результати досліджень та їх обговорення. Безпосередні результати операції ми оцінювали комплексно на підставі міри зміни клінічного статусу і наявності післяопераційних ускладнень. У пацієнтів першої групи на тлі призначеної консервативної терапії спостерігалося збереження відсо-

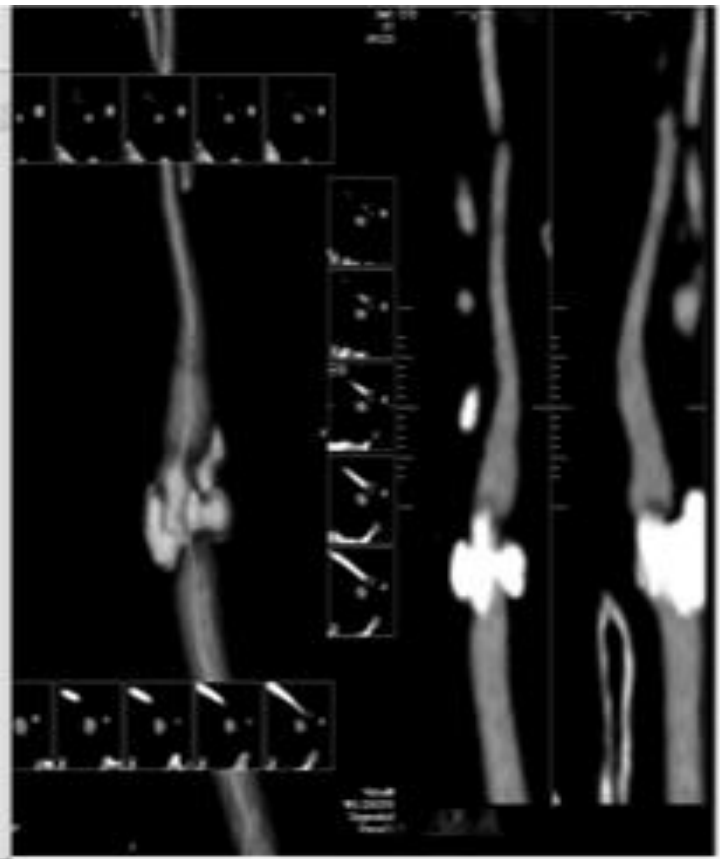

тка стенозу, при цьому у 2 хворих відсоток стенозу ВСА збільшився на 5-10\%. У 11 хворих другої групи в післяопераційному періоді не виявлено ускладнень у вигляді інсульту, кровотечі, втрати зору, у двох хворих визначався реперфузійний синдром у вигляді головного болю на третю добу, який купірувався самостійно протягом тижня. Усі пацієнти другої групи були виписані в стабільному стані. Таким чином, нам вдалося досягти поліпшення в клінічному статусі хворого в $85 \%$ випадків упродовж 3 місяців після операції і скоротити кількість ішемічних інсультів, при оклюзії a.ophtalmica - хірургічне лікування дозволяє поліпшити гостроту і поля зору. У перші 24 години пряму ознаку гострого ішемічного порушення мозкового кровообігу не вдавалося виявити. При повторному КТ обстеженні через 7-21 днів зона інфаркту дещо зменшувалась в розмірі, ставала більш чітко окресленою за рахунок абсорбції некротичної тканини. Неврологічний дефіцит за шкалою змінювався на 3-5 балів у хворих середнього ступеня (рис. 2 та 3).

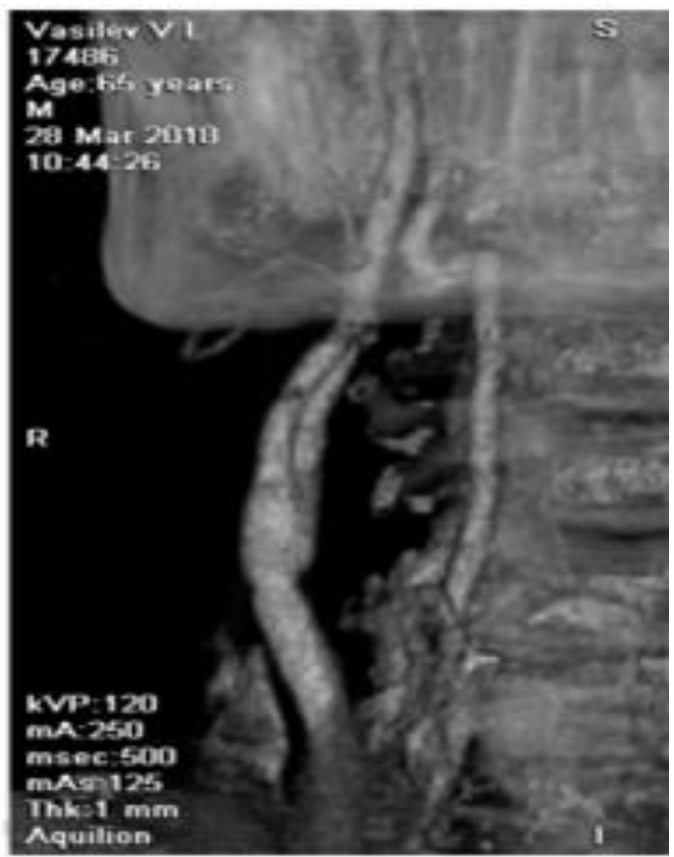

Рис. 2. КТ до каротидної ендартеректомії та після іï виконання.

Висновки. 1. Пацієнти із симптоматичним ураженням ВСА, великим вогнищем інсульту, білатеральним враженням сонних артерій $\epsilon$ найбільш високо ризиковою групою щодо розвитку повторного інсульту та реперфузійного синдрому.

2. При гемодинамічно значимих стенозах або наявності нестабільної бляшки, підтвердженими даними СКТ із контрастуванням необхідно виконувати каротидну ендартеректомію, важливим $€$ розмір ішемічного вогнища, соматичний стан i рівень неврологічного дефіциту при виборі методу лікування.

Інформація про конфлікт інтересів. Конфлікту інтересів немає.

Інформація про фінансування. Автор гарантує, що він не отримував жодних винагород у будь-якій формі, здатних вплинути на результати роботи.

Особистий внесок кожного автора у виконання роботи:

Пуляєва І.С. - ідея, мета, збір матеріалу дослідження, аналіз отриманих результатів, підготовка тексту статті.

Науковий вісник Ужггородського університету, серія «Медииина», випуск 1 (61), 2020 p. 


\section{Список використаної літератури}

1. A clinical approach to the management of the patient with coronary (Co) and/orcarotid (Ca) artery disease who presents with legischaemia (Lis) / DL Clement, H Boccalon, J Dormandy [etal.] // IntAngiol. 2000. Vol.19. P. 97-125.

2. Antithrombotic therapy in acute ischaemic stroke: anover view of the completed randomised trials / P.A.Sandercock, A.G.vandenBelt, R.I.Lindley [et al.] // J Neurol Neurosurg Psychiatry. 1993. Vol.56. P.17-25.

3. Asymptomatic Carotid Stenosisand Risk of Stroke (ACSRS) Study Group. Effect of image normalization on carotid plaque classification and the risk of ipsilateral hemisphericischemic events: results from the asymptomatic carotid stenosis and risk of stroke study / AN Nicolaides, SK Kakkos, M Griffin [etal.] // Vascular. 2005. Vol.13. - P.211-221.

4. American Heart Association Statistics Committeeand Stroke Statistics Subcommittee. Heart disease and stroke statistics. 2006 update: a report from the American Heart Association Statistics Committeeand Stroke Statistics Subcommittee / T.Thom, N.Haase, W Rosamond [etal.] // Circulation. - 2006. -Vol.113. - P.85-151.

5. Contemporary management of contaminant carotid and coronary artery disease / S. Venkatachalam [et al.] // Heart. 2011. Vol. 97 (3). P. 175-180.

6. Current status of carotid bifurcation angioplasty and stenting based on a consensus of opinion leaders / F.J.Veith, M.Amor, T.Ohki [et al.] // J VascSurg. - 2001. Vol.33 (2 Suppl). S111-S116.

7. Incidence and short-term prognosis of transienti schemic attack in a population-based study / D.Kleindorfer, P.Panagos, A.Pancioli [et al.] // Stroke. 2005. Vol.36. P.720-723

Стаття надійшла до редакції: 23.01 .2020 р. 